\title{
Effects of Nitrogen Fertilization on Some Turfgrass Characteristics of Perennial Ryegrass (Lolium perenne
}

\section{L.)}

Hakkı Akdeniz ${ }^{1}$ and İbrahim Hosaflıoğlu ${ }^{2}$

1. Field Crops Department, Agricultural Faculty, Iğdır University, Iğdır-7600, Turkey

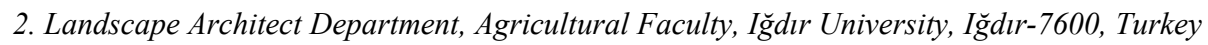

\begin{abstract}
The paper aimed to study the effects of nitrogen fertilization on the yield and some plant characteristics of perennial ryegrass (Lolium perenne L.). The study was conducted at Agricultural Research and Application Center of the Faculty of Agriculture in Iğdır University in 2013. In the experiment, eight levels of fertilizers: 0, 10.0, 20.0, 30.0, 40.0, 50.0, 60.0 and 70.0 kg $\mathrm{N} /$ ha per month were applied in perennial ryegrass (Lolium perenne L.) during the sixth growing season. A randomized complete block with three replications was used as the experimental design. Nitrogen application affected plant height, green grass yield, plant covering rate, canopy color and turfgrass quality values of perennial ryegrass positively. In both monthly and as the average of nitrogen application, times of application (spring, summer and fall) caused the most uniform turfgrass quality and establishment. Results indicated that although a significant impact was on the character investigated, such as the leaf length, green grass yield, plant cover ratio, canopy color and turfgrass quality, the doses of nitrogen fertilizer have created close to each other in groups. In the stand point of view of all characters, N1, N2 and N3 were located in first group, N4 and N5 in the second group, N6 and N7 in the third group, expect for control (N0). It can be concluded that 40.0-50.0 kg N/ha per month may be more suitable to be used in ryegrass production in the landscape.
\end{abstract}

Key words: Ryegrass, Lolium perenne L., nitrogen fertilization, turfgrass quality.

\section{Introduction}

Perennial ryegrass is a persistent, dark green, fineto medium-textured turfgrass that is used for home lawns, parks, grounds, golf courses and athletic fields. This species produces a bunch-type growth habit and does not form rhizomes or stolons. Perennial ryegrass germinates rapidly (5-7 d) and establishes quickly. It is very competitive with other turfgrasses and is used extensively for overseeding thin or damaged turf [1]. Nitrogen $(\mathrm{N})$ is one of the major mineral nutrients required by plants, providing the building blocks for growth and physiological functioning. $\mathrm{N}$ also stimulates plant shoot and root growth and development, and is essential for carbohydrate use in plants. In general, higher rates of fertilization with $\mathrm{N}$

Corresponding author: Hakk1 Akdeniz, associate professor, research fields: range management and forage crops. deliver the better quality of turf, regardless of fertilizer sources [2]. Fertilization programs generally are built around this element. In regions where in warm-season grasses are dormant during part of the year and overseeding is not employed, the need for $\mathrm{N}$ fertilization will vary throughout the year [3]. The information available in the literature concerning the stability of plantations of perennial ryegrass is equivocal. It is commonly reported that perennial ryegrass gives the highest yield in the first year of use $[4,5]$. Perennial ryegrass stability in cultivation for seeds depends on natural habitat conditions [6], cultivar physiological properties (the growth rate, ageing, the time of seed ripening) and the way of utilization, as well as on agronomic factors [7] shaping plant growth, development and yielding. Y1lmaz et al. [8] determined that turf culture gained 
significance in the country during recent years. Also, there are many landscapes in turf establishment and management activities in this sector. Since the proper techniques are not imposed during turf studies, turf areas are lost in a very short period deteriorated. The main problems are lack of experienced stuff and infrastructure, effect from different ecologies, failures in genus and species preferences, overuse of seed supplies, lack of high-quality seed sources and lack of maintenance measures.

Perennial ryegrass responds strongly to $\mathrm{N}$. Falkowski et al. [9] reported that $\mathrm{N}$ when applied at the beginning of vegetation affects formation and development of inflorescences. Higher doses of mineral $\mathrm{N}$ result in an increase in some generative tillers [10]. Apart from generative tillers, also, vegetative shoots develop intensively at a high level of $\mathrm{N}$ fertilization of perennial ryegrass. The goal for a fertilization program should be to apply the least amount of fertilizer needed to produce healthy turf, while meeting the aesthetic and functional standards for the area. $\mathrm{N}$ is the element most needed by turfgrass for growth and is at the center of most fertilization programs. While $\mathrm{P}$ and $\mathrm{K}$ are essential nutrients, lawns require much less to sustain adequate plant health and growth.

The aim of this research was to determine, under the optimum moisture regime, the effect of rate of $\mathrm{N}$ application on perennial ryegrass on green grass yield, plant height, plant cover rate, colour and turfgrass quality.

\section{Materials and Methods}

\subsection{Experiment Area}

Field trials were established, and research was conducted at Agricultural Research and Application Center of the Faculty of Agriculture in Iğdır University in Northeastern Turkey during May to September of 2013. As far as $\mathrm{pH}$ values, organic matter levels and nutrient content of the soil are concerned, chemical analysis is widely used. Field experiments were carried out on clay soil, $\mathrm{pH} 8.39$, plant available $\mathrm{P}_{2} \mathrm{O}_{5} 16.0 \mathrm{mg} / \mathrm{kg}$ and $\mathrm{K}_{2} \mathrm{O} 168.3 \mathrm{mg} / \mathrm{kg}$, and soil organic matter content $1.18 \mathrm{mg} / \mathrm{kg}$ in autumn of the year before sowing.

\subsection{Experiment Design}

In the trials, Perennial ryegrass cv. "Bolida" (germination $99 \%$ ) was sown at a rate of $40 \mathrm{~g} / \mathrm{m}^{2}$ in the plots in mid-May using by hand. Hand seeding is most practical where small areas are to be established. The plots consisted of $2 \mathrm{~m} \times 1 \mathrm{~m}, 1 \mathrm{~m}$ distance was left between blocks and between plot to prevent interplant and cultural activities effect on the plants. In the trial, eight levels of fertilizers were compared: 0 , $10.0,20.0,30.0,40.0,50.0,60.0$ and $70.0 \mathrm{~kg} \mathrm{~N} /$ ha per month during the growing season. Ammonia sulfate was used as $\mathrm{N}$ source. A randomized complete block with three replications was used as the experimental design. Turf was evaluated visually for quality and color, which were rated immediately after mowing. A scale of 1-9 was used, in which 9 represents the optimal, dark green color and 1 represents dead, brown turf [11].

Depending on the year and the standards that have set for the lawn, irrigation will be needed from mid-May to early September. In this experiment, for a new irrigation system, the primary goal is to design a system that applies water efficiently and uniformly. Water has the greatest influence on turf health and quality. Irrigation required to maintain the soil $70 \%$ of field capacity was established by sprinkle system in the experimental area during the growing season. There was no need for more than a weed, when Lolium perenne $\mathrm{L}$. was observed by a fast coating rate for a very fast, except for some weeds. However, mechanical methods were used to combat weeds for this purpose by hacksaw blade.

The general rule is to never remove more than one-third of the leaf blade at any one time. When they reach 7-8 $\mathrm{cm}$ in paint, plants in the plot are cut to 3-4 cm stubble. 


\subsection{Statistical Analysis}

The data were subjected to analysis of variance, using the SAS statistical package [12]. The means were separated using the Duncan multiple range test (DMRT). Also, cluster, for a review of the general categories of cluster analysis methods, and principal components analysis (PCA) were applied to preserve as much information contained in the data as possible.

\section{Results and Discussion}

In the experiment year, the temperatures ranged from $20{ }^{\circ} \mathrm{C}$ to $25{ }^{\circ} \mathrm{C}$, and it has increased by $4.9 \%$ compared to the data of long years (Fig. 1). The perennial ryegrass is best adapted to cool, moist climates, where winter kill is not a problem. The average temperature of December is under the normal in 2013. Rainfall was above normal (Fig. 2).

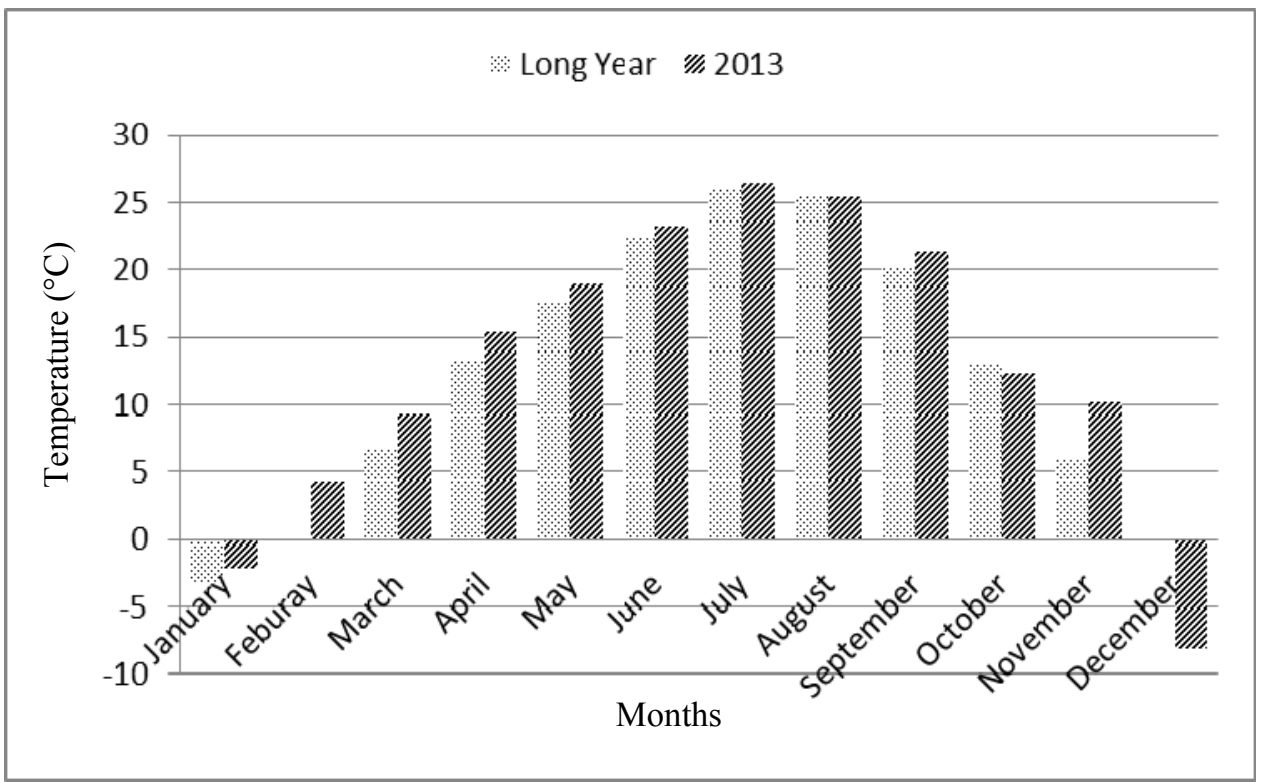

Fig. 1 Temperature deals with months.

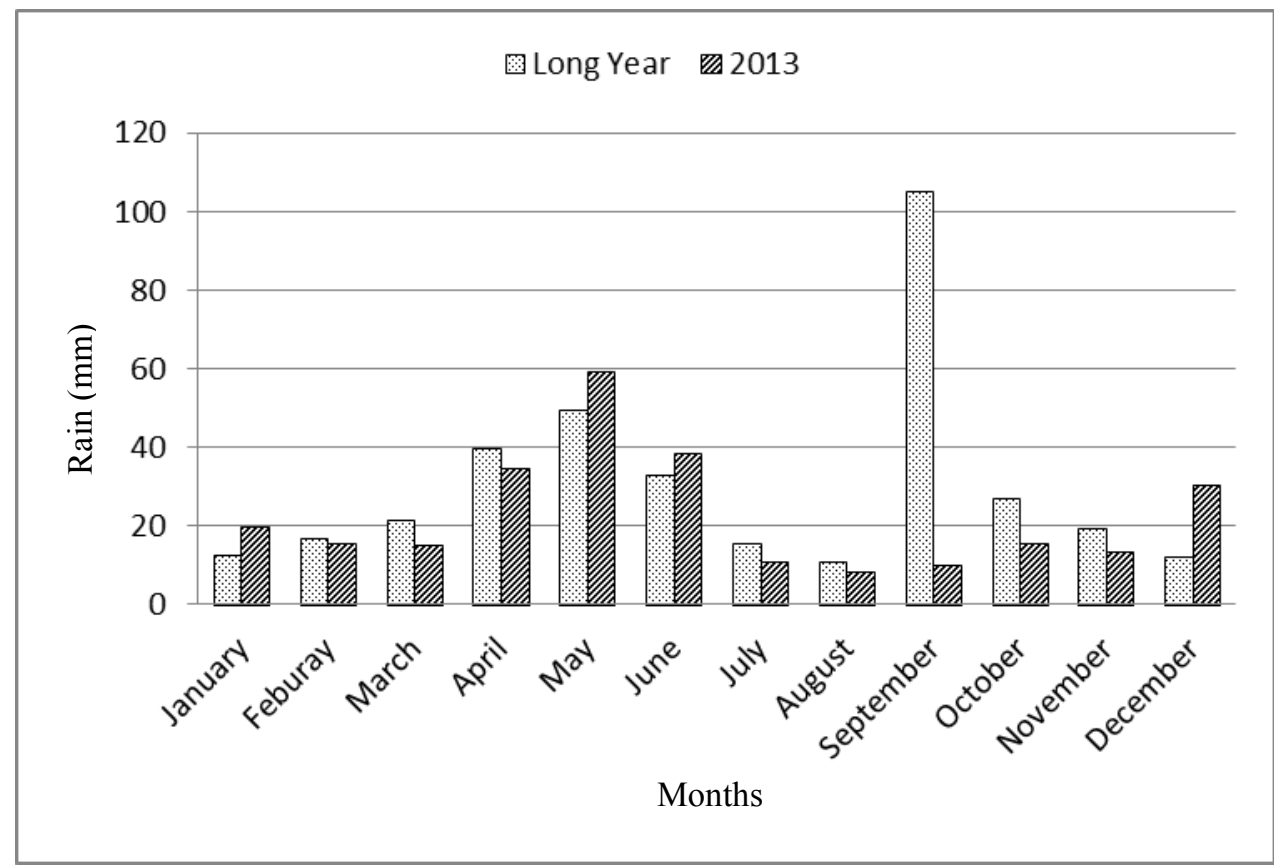

Fig. 2 Rainfall in 2013 compared with long year. 


\subsection{Leaf Length}

Leaf length $(\mathrm{cm})$ was measured with a ruler, from the leaf tip to the point of emergence from the enclosing sheath of the next oldest leaf. There were 3-6 leaves on the main tiller measured on 10 plants for each plot. Leaf length of the perennial ryegrass (Lolium perenne L.) was stimulated at higher $\mathrm{N}$ levels (N7, N6, N5 and N4) (Table 1 and Figs. 3 and 4). The lowest value was obtained from the plot which is not applied $\mathrm{N}$ fertilizer. That is to say that length data ranged from $14.9 \mathrm{~cm}$ to $20.1 \mathrm{~cm}$. No significant difference was detected among the plant length at these levels of nutrients. Leaf length is a key factor in the economic value of different grass species and cultivars in forage production. It is also important for the survival of individual plants within a sward [13]. Many studies have been conducted to determine the morphological and physiological traits, which could explain vegetative yield variation in swards. It is important to remember that leaf length in grasses is

Table 1 Effects of $\mathrm{N}$ application on plant cover and some plant characteristics of perennial ryegrass (Lolium perenne L.).

\begin{tabular}{llllll}
\hline N rate $(\mathrm{kg} / \mathrm{ha})$ & Leaf length $(\mathrm{cm})$ & Green grass yield $\left(\mathrm{g} / \mathrm{m}^{2}\right)$ & Plant cover ratio $(\%)$ & Canopy color & ${\text { Turfgrass quality }(1-9)^{*}}^{\mathrm{d}}$ \\
\hline $\mathrm{N} 0$ & $14.9^{\mathrm{d}}$ & $2,548^{\mathrm{e}}$ & $75.6^{\mathrm{f}}$ & $5.9^{\mathrm{c}}$ & $4.7^{\mathrm{c}}$ \\
$\mathrm{N} 1$ & $15.6^{\mathrm{cd}}$ & $2,651^{\mathrm{de}}$ & $76.7^{\mathrm{ef}}$ & $6.0^{\mathrm{c}}$ & $4.8^{\mathrm{c}}$ \\
$\mathrm{N} 2$ & $16.8^{\mathrm{bcd}}$ & $2,885^{\mathrm{ab}}$ & $77.2^{\mathrm{de}}$ & $6.3^{\mathrm{c}}$ & $5.2^{\mathrm{c}}$ \\
$\mathrm{N} 3$ & $15.6^{\mathrm{cd}}$ & $2,807^{\mathrm{cd}}$ & $78.0^{\mathrm{d}}$ & $7.3^{\mathrm{b}}$ & $5.3^{\mathrm{c}}$ \\
$\mathrm{N} 4$ & $17.2^{\mathrm{bc}}$ & $3,072^{\mathrm{a}}$ & $84.0^{\mathrm{c}}$ & $8.2^{\mathrm{a}}$ & $6.9^{\mathrm{b}}$ \\
$\mathrm{N} 5$ & $17.8^{\mathrm{ab}}$ & $2,892^{\mathrm{ab}}$ & $85.8^{\mathrm{bc}}$ & $8.4^{\mathrm{a}}$ & $7.7^{\mathrm{a}}$ \\
$\mathrm{N} 6$ & $18.9^{\mathrm{ab}}$ & $3,000^{\mathrm{ab}}$ & $87.3^{\mathrm{a}}$ & $8.1^{\mathrm{a}}$ & $7.4^{\mathrm{ab}}$ \\
$\mathrm{N} 7$ & $20.1^{\mathrm{a}}$ & $2,933^{\mathrm{ab}}$ & $86.4^{\mathrm{ab}}$ & $8.0^{\mathrm{a}}$ & $7.7^{\mathrm{a}}$ \\
\hline Seasons & & & & \\
\hline Spring & $15.2^{\mathrm{c}}$ & $2,736^{\mathrm{b}}$ & $80.5^{\mathrm{c}}$ & $8.1^{\mathrm{a}}$ & $5.6^{\mathrm{b}}$ \\
Summer & $16.5^{\mathrm{b}}$ & $2,657^{\mathrm{b}}$ & $81.4^{\mathrm{b}}$ & $6.3^{\mathrm{c}}$ & $6.0^{\mathrm{b}}$ \\
Fall & $21.4^{\mathrm{a}}$ & $3,152^{\mathrm{a}}$ & $83.1^{\mathrm{a}}$ & $7.8^{\mathrm{b}}$ & $7.0^{\mathrm{a}}$ \\
\hline
\end{tabular}

There were no significant differences at $P<0.05$ level among averages shown with the same letter.

${ }^{*}$ Turfgrass quality ratings: $1=$ dead, $9=$ ideal.

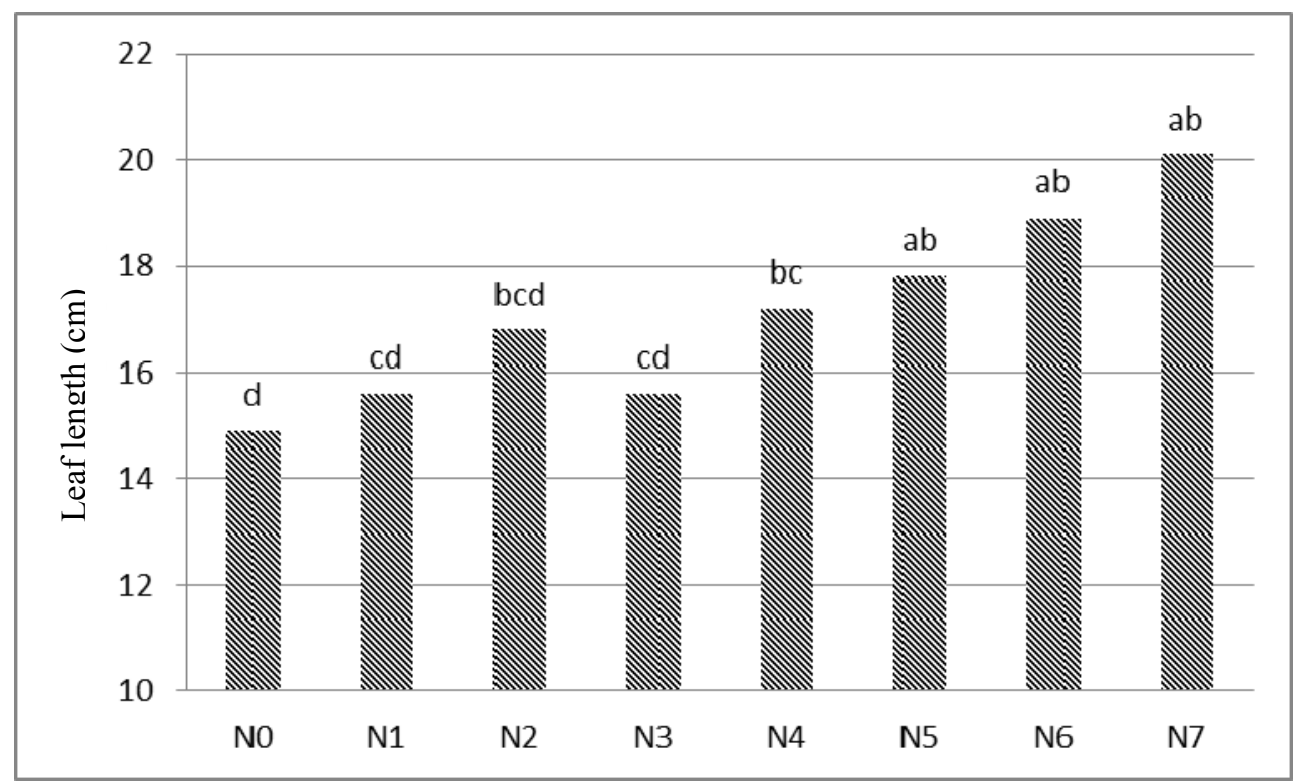

Fig. 3 Effects of $\mathbf{N}$ fertilization on the leaf length of Lolium perenne $\mathbf{L}$..

In each column, the same letters are not significantly different using DMRT at 5\% probability level. 


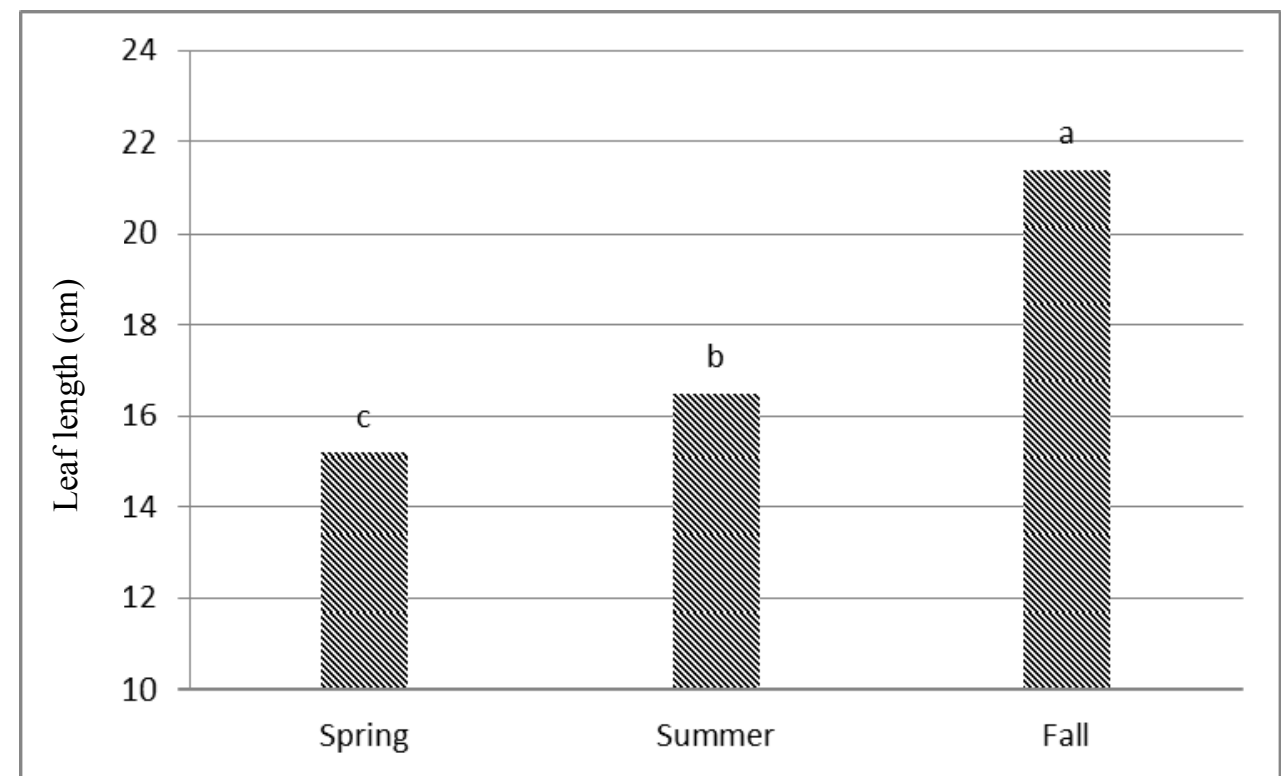

Fig. 4 Effects of seasons on the leaf length $(\mathrm{cm})$ of Lolium perenne L..

In each column, the same letters are not significant different using DMRT at 5\% probability level.

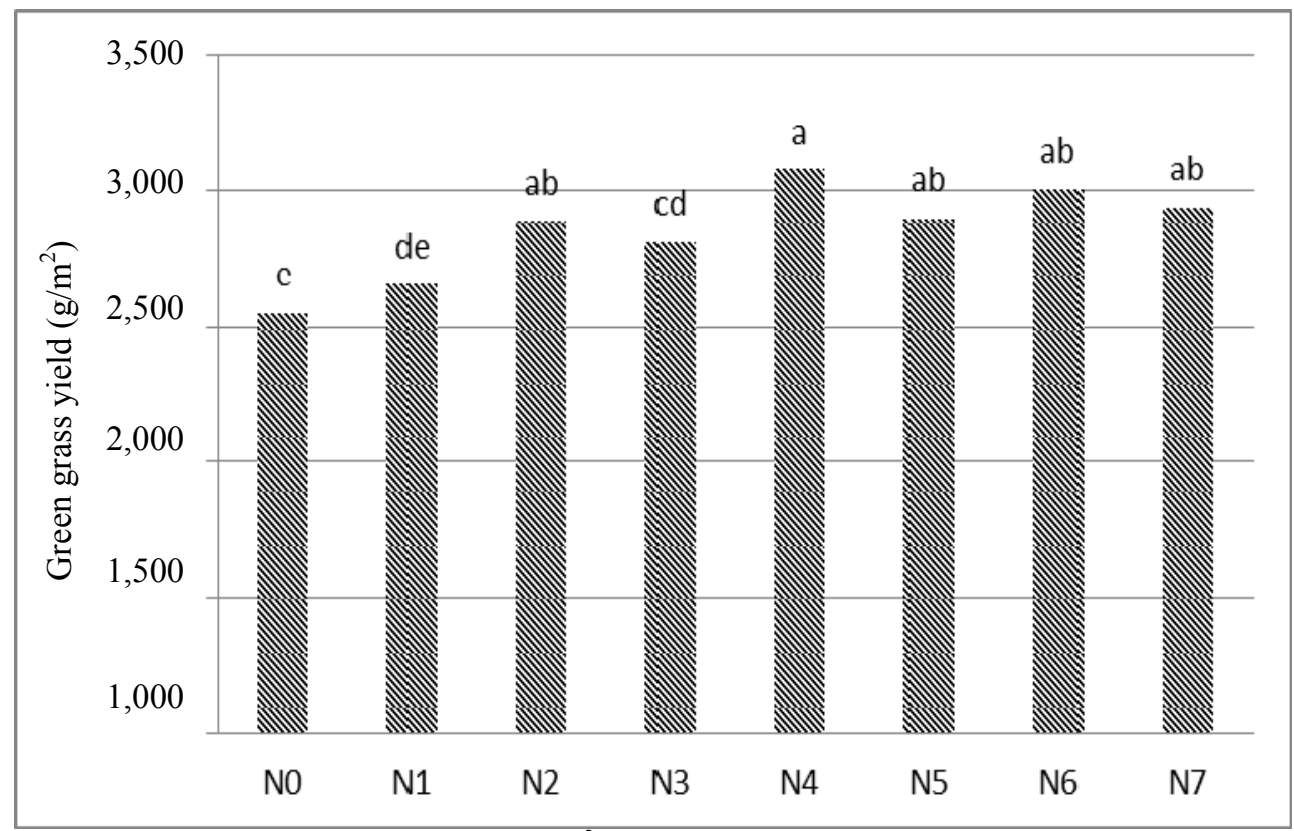

Fig. 5 Effects of $\mathbf{N}$ fertilization on green grass yield $\left(\mathrm{g} / \mathrm{m}^{2}\right)$ of Lolium perenne $\mathrm{L}$..

In each column, the same letters are not significant different using DMRT at 5\% probability level.

greatly influenced by the developmental stage of the plant, i.e., reproductive or vegetative stage [14]. Some of findings are consistent with those of Zorer et al. [15], who also showed that spring, fall and spring fertilizer applications affected turfgrass character as periodically, and growth, turfgrass quality and color values decreased when the effect of $\mathrm{N}$ is decreased. In addition, as mentioned, plant height, green herbage, color and turfgrass quality values were pretty similar when $\mathrm{N}$ was applied monthly and seasonally.

\subsection{Green Grass Yield}

Increase in $\mathrm{N}$ fertilizer application slightly increased green grass yield in 2013 year (Table 1 and Fig. 5). The green grass yield responses followed the same pattern as leaf length, i.e., significantly 
decreased at lower nutrient (N0 (no fertilizer) and N1) levels of application. However, statistically, there was no difference detected in the green grass yield at these two nutrient levels. Also, differences in green grass yield among the N4, N5, N6 and N7 levels of N doses were not significant. Soil moisture holding capacity of some plots may also explain differences in experimental measurements observed. Consequently, $\mathrm{N}$ fertilizer rate provided a small amount increase in green grass yield by $8 \%-9 \%$ compared to the untreated plots (no $\mathrm{N}$ applied).

The leaf length of Lolium perenne L. has reached the longest leaf size in the fall season (Fig. 4). Cool season turfgrass includes species that are adapted to the cooler portions of the world and make the maximum growth during cool spring and fall weather. They may become semi-dormant during hot and dry periods of summer as seen in Fig. 6. It has been suggested that $\mathrm{N}$ rates to cool-season lawn turf could be reduced by as much as $33 \%$ to $50 \%$ when clipping is returned [16]. As observed by other researchers, the increase was a result of many factors in changing soil microenvironment, including soil water content and organic $\mathrm{C}$ and $\mathrm{N}$ levels. Other factors in addition to $\mathrm{N}$ solubility will affect the leaching potential from turf, and these include, but are not limited to, soil type, irrigation rate, $\mathrm{N}$-application rate, frequency and timing of fertilizer applications, stand density, rooting characteristics and plant $\mathrm{N}$ demands. Petrovic et al. [17] and Wilman and Pearse [18] showed that N fertilization is determinant for pasture productivity, as it results in increasing forage yield and is associated with the growth physiology of forage plants. The rate of tiller development, evaluated in each of the seven-day periods, was affected by $\mathrm{N}$ rates and time of application.

\subsection{Plant Cover Ratio}

Lolium perenne $\mathrm{L}$. does not produce stolons or rhizomes, its shoot buds arise at or near the soil level in young plants but may develop from higher nodes in large single plants. The lowest plant cover ratio was obtained from $75.6 \%$ in the plot N0, the highest plant cover ratio was $87.3 \%$ (Table 1 and Fig. 7). However, it had a slight difference between the plants in fertilized and unfertilized plots, and on the other hand, covering ratio of Lolium perenne was very high in fertilized plots. As seen in Table 1 and Fig. 8, there was a linear increasing on plant covering ratio in relating to seasons. At the same time, spring and fall are the seasons of the best growth; during the hot summer months, perennial ryegrass becomes dormant.

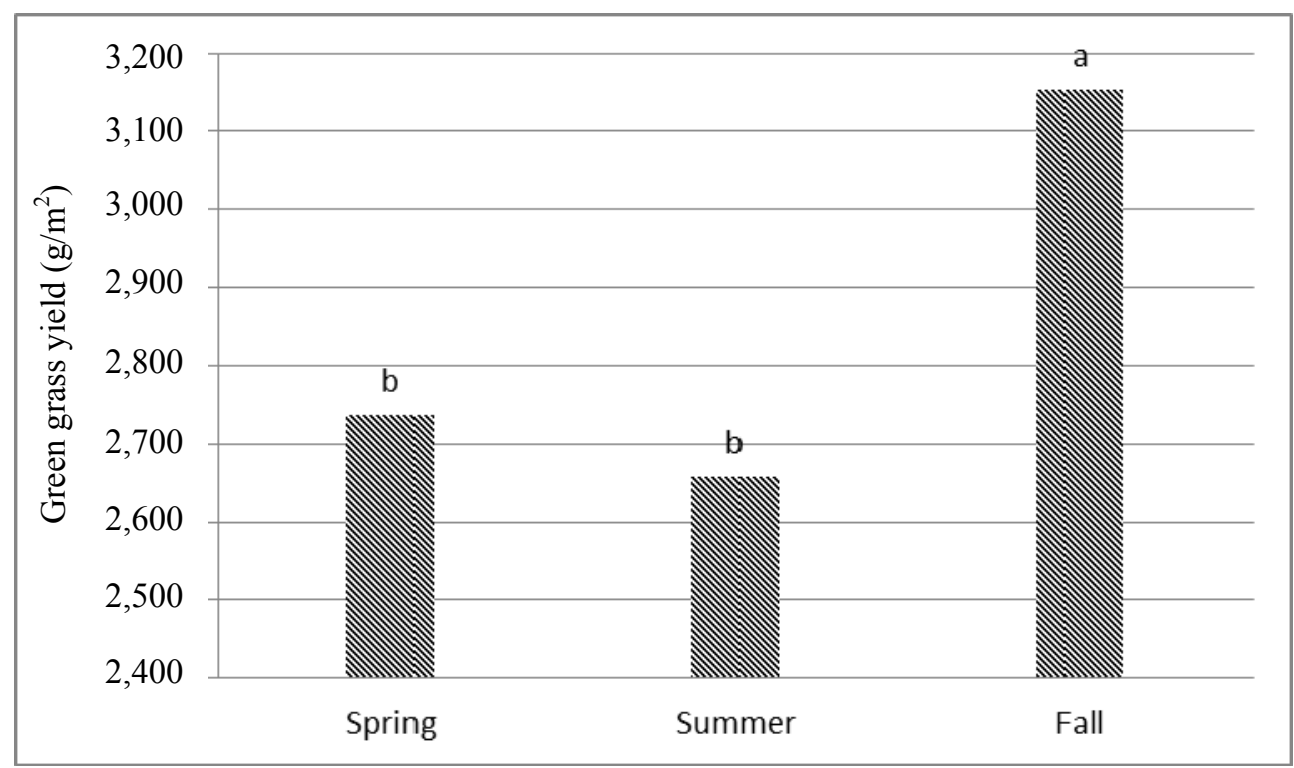

Fig. 6 Effects of seasons on plant green grass yield of Lolium perenne $\mathrm{L}$..

In each column, the same letters are not significant different using DMRT at 5\% probability level. 


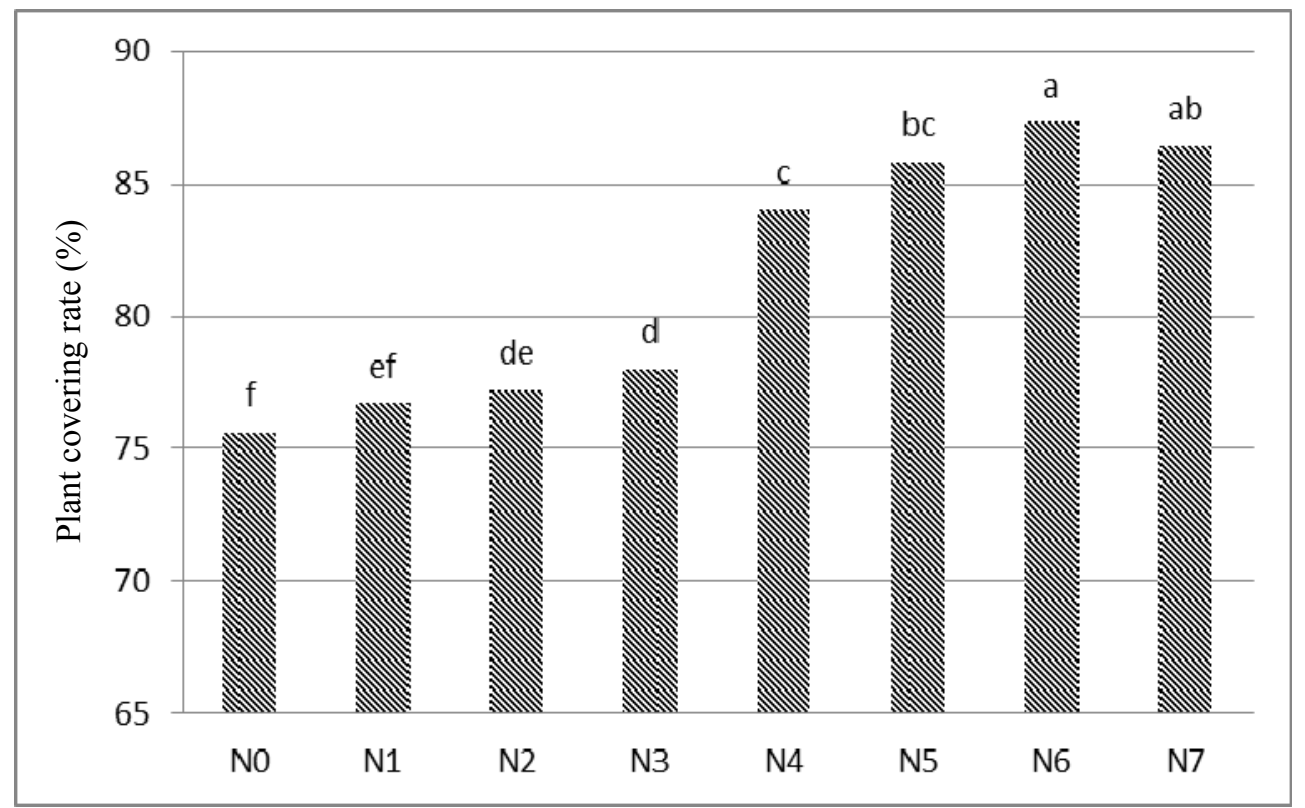

Fig. 7 Effects of $\mathbf{N}$ fertilization on covering rate of Lolium perenne $\mathbf{L}$..

In each column, the same letters are not significant different using DMRT at 5\% probability level.

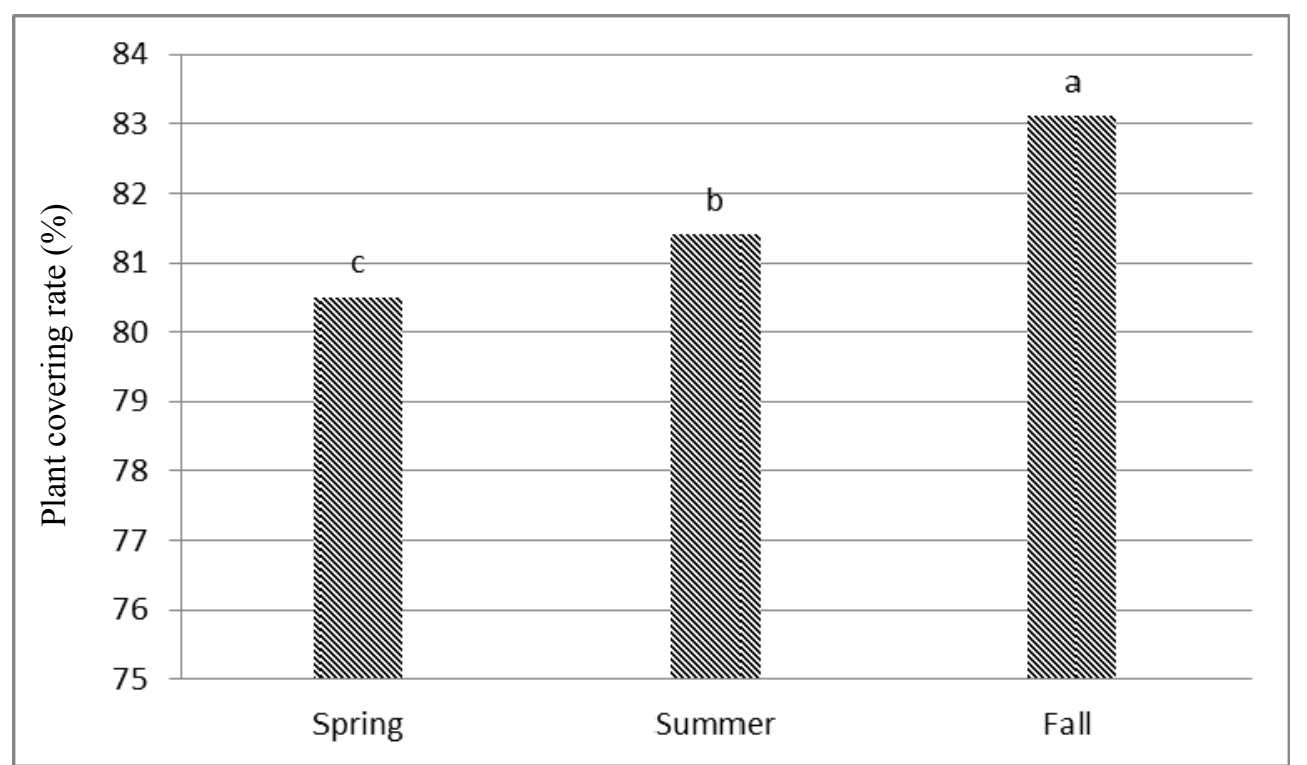

Fig. 8 Effects of seasons on covering rate of Lolium perenne $\mathrm{L}$..

In each column, the same letters are not significant different using DMRT at 5\% probability level.

In this experiment, the maximum temperatures ranged from $20{ }^{\circ} \mathrm{C}$ to $25{ }^{\circ} \mathrm{C}$. The perennial ryegrass is best adapted to cool, moist climates where winter kill is not a problem. However, Szczepanek [7] showed that in the first and second year, $\mathrm{N}$ fertilizer application in a dose of $60 \mathrm{~kg} / \mathrm{ha}$ was sufficient. In the third year, increasing the dose by $30 \mathrm{~kg} / \mathrm{ha} \mathrm{N}$ prevented a decrease in perennial ryegrass plant productivity. Plant roots can be very effective in the fall season (Fig. 8), but they need to be stimulated by the presences of nutrients, notable $\mathrm{N}$ and $\mathrm{P}$, to branch out and explore new areas. Perennial ryegrass generated significantly more generative tillers in the spring season as compared to fall during the growing season. Response to $\mathrm{N}$ related to increasing on tiller density has been reported by Wilman and Pearse [18] for some grass species, such as perennial ryegrass (Lolium perenne L.), and Harris et al. [19] verified an increase in tiller weight for perennial 
ryegrass after $\mathrm{N}$ application. Leaf length in grasses plays an essential role in shaping the physical structure of the canopy and consequently on competition for light within the sward. One of the major adaptive responses to light competition in plants is an increase of plant height, i.e., leaf length during the vegetative period in grasses $[13,20]$.

\subsection{Canopy Color}

One of the most important features that reveal the quality of green space is the color. In the control plot, $\mathrm{N}$ application, despite low level, has a positive effect on color values. After fertilizing applied, increase in color value was observed from near the dark green color tone, and the percent of green canopy cover decreased only at the lower nutrient (N0 and N1) levels (Table 1, Figs. 9 and 10). In general, a rate of N4, N5, N6 and N7 resulted in more uniform turf visual color and higher visual quality. In agreement with the results of this study, $\mathrm{N}$ along $\mathrm{Mg}$ is also found

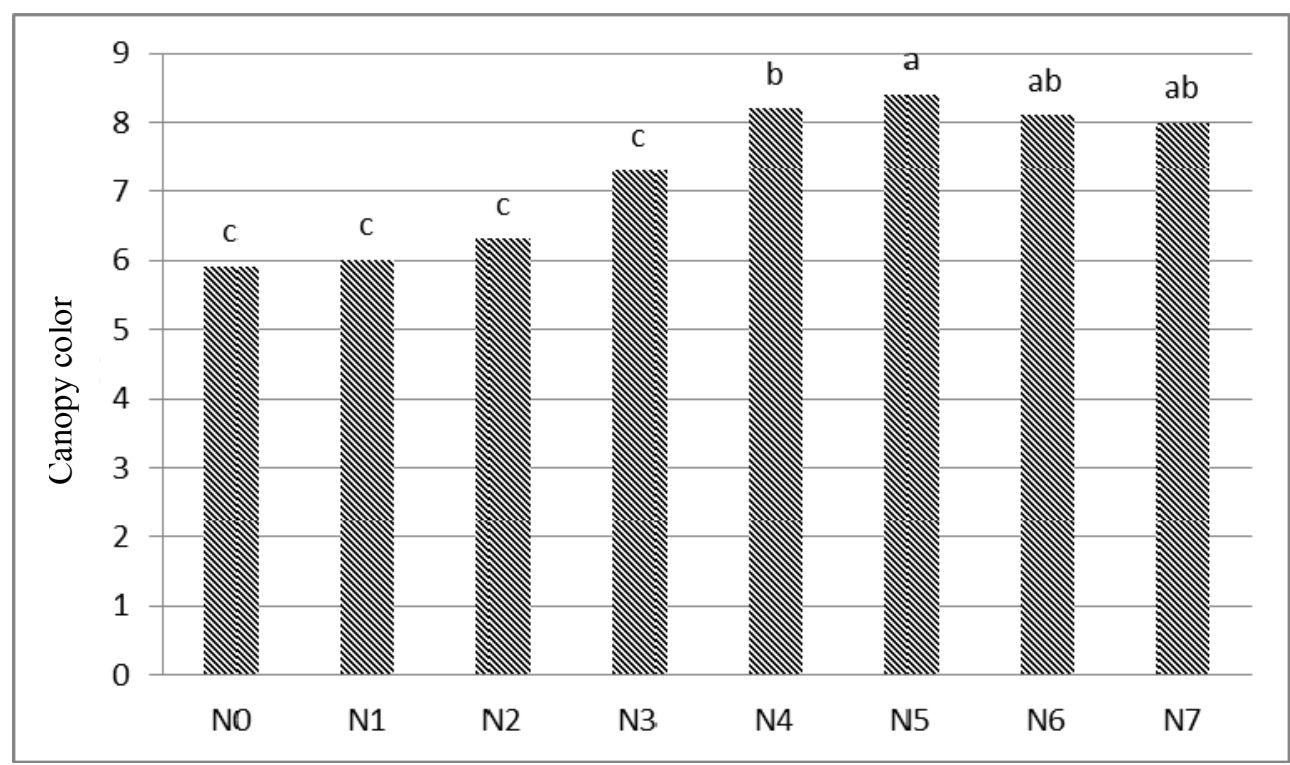

Fig. 9 Effects of $\mathbf{N}$ fertlization on the canopy color of Lolium perenne $\mathbf{L}$..

In each column, the same letters are not significant different using DMRT at $5 \%$ probability level.

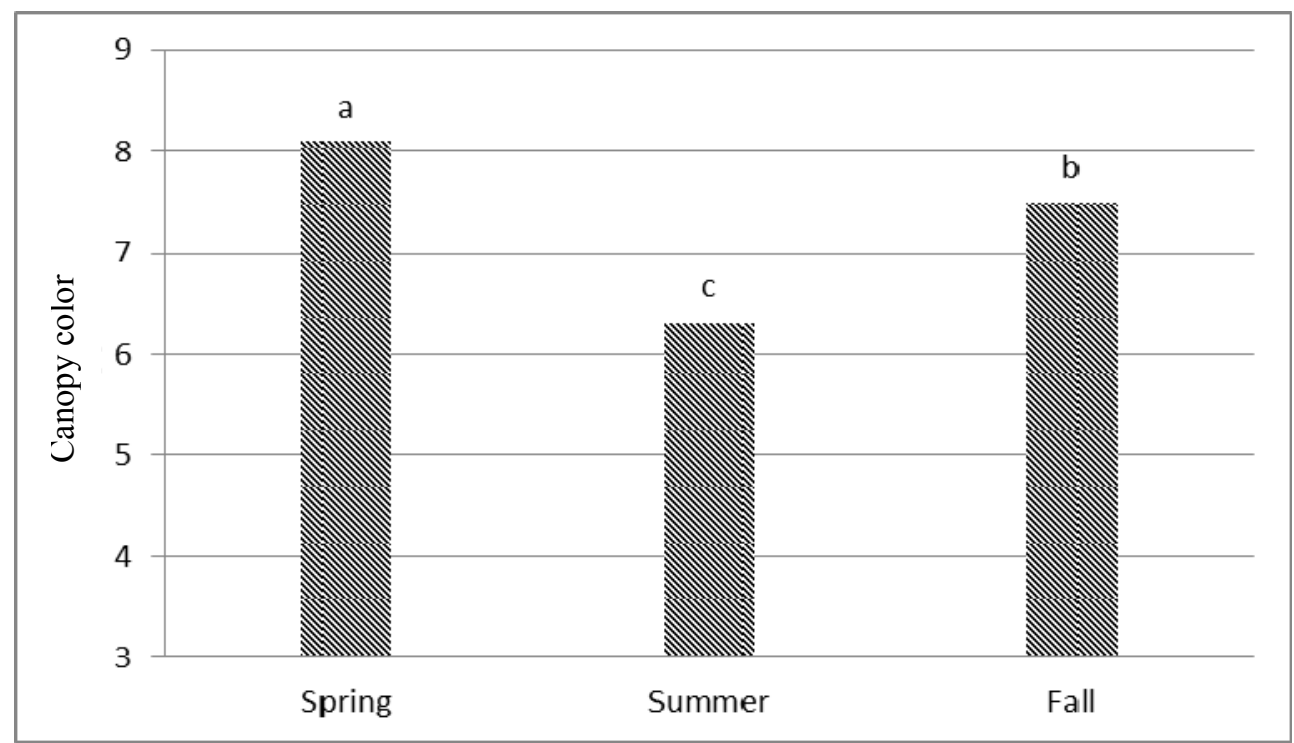

Fig. 10 Effects of seasons on canopy color of Lolium perenne $\mathrm{L}$..

In each column, the same letters are not significant different using DMRT at 5\% probability level. 
in the central structure of chlorophyll and in the structure of proteins that are spread in all green parts of grasses. This is why $\mathrm{N}$ plays a primary role in the growth of grasses, leaves growth, shoot growth, rhizomes growth and also in the retaining of green color of turf [3]. Matching irrigation to turfgrass requirements has been shown to improve $\mathrm{N}$ uptake, growth and color of turfgrass maintained with water-soluble fertilizer [21]. In addition to fertilizer type, irrigation regimes can also affect the efficiency of $\mathrm{N}$ fertilizers. However, Goatley at. al [22] pointed out that $\mathrm{N}$ applications provided a linear increase in $\mathrm{N}$, $\mathrm{P}$ and $\mathrm{K}$ concentrations in the leaves. Late-season application of $\mathrm{N}$ improved fall and spring Bermuda grass color. However, Heckman et al. [2] observed that turfgrass colour ratings at $98 \mathrm{~kg} / \mathrm{ha} \mathrm{N}$ were generally better than those at $196 \mathrm{~kg} / \mathrm{ha}$.

\subsection{Turfgrass Quality}

The data also showed close relation between turfgrass quality and $\mathrm{N}$ fertilizer. When compared to the control plot, $\mathrm{N}$ rates were found to have a significant effect on quality of Lolium perenne L. during sixth-month periods tested in 2013 (Table 1).
In general, as $\mathrm{N}$ fertilization rate increased, turfgrass quality also increased (Fig. 11). Higher quality was observed with N5, N6 and N7 fertilizers (50.0, 60.0 and $70.0 \mathrm{~kg} \mathrm{~N} / \mathrm{ha}$ in the month), while lower quality was from N1, N2, N3 and N4 applications, including control plot N0. However, there was no difference between N5, N6 and N7 fertilizers, statistically. However, the fall season was found to have a significant effect on the quality of perennial ryegrass, and there was no significant effect statistically between spring and summer seasons (Fig. 12). Candogan et al. [23] stated that turfgrass evapotranspiration varies by seasonal, and visual color, quality and clipping yield were shown to decrease significantly with decreases in irrigation water and $\mathrm{N}$ fertilizer. In both cases, by adjusting $\mathrm{N}$ fertilizer rates and water supply, turfgrass visual color and quality will be able to be maintained. Similarly, Barton et al. [24] also recommend that under the low irrigation treatment, inorganic $\mathrm{N}$ fertilizers applied at 200-300 $\mathrm{kg} \mathrm{N} /$ ha were adequate for the production of turfgrass sod. Many studies have considered the effects of various $\mathrm{N}$ fertilization rates on quality, but very few have included the practice of returning grass clippings.

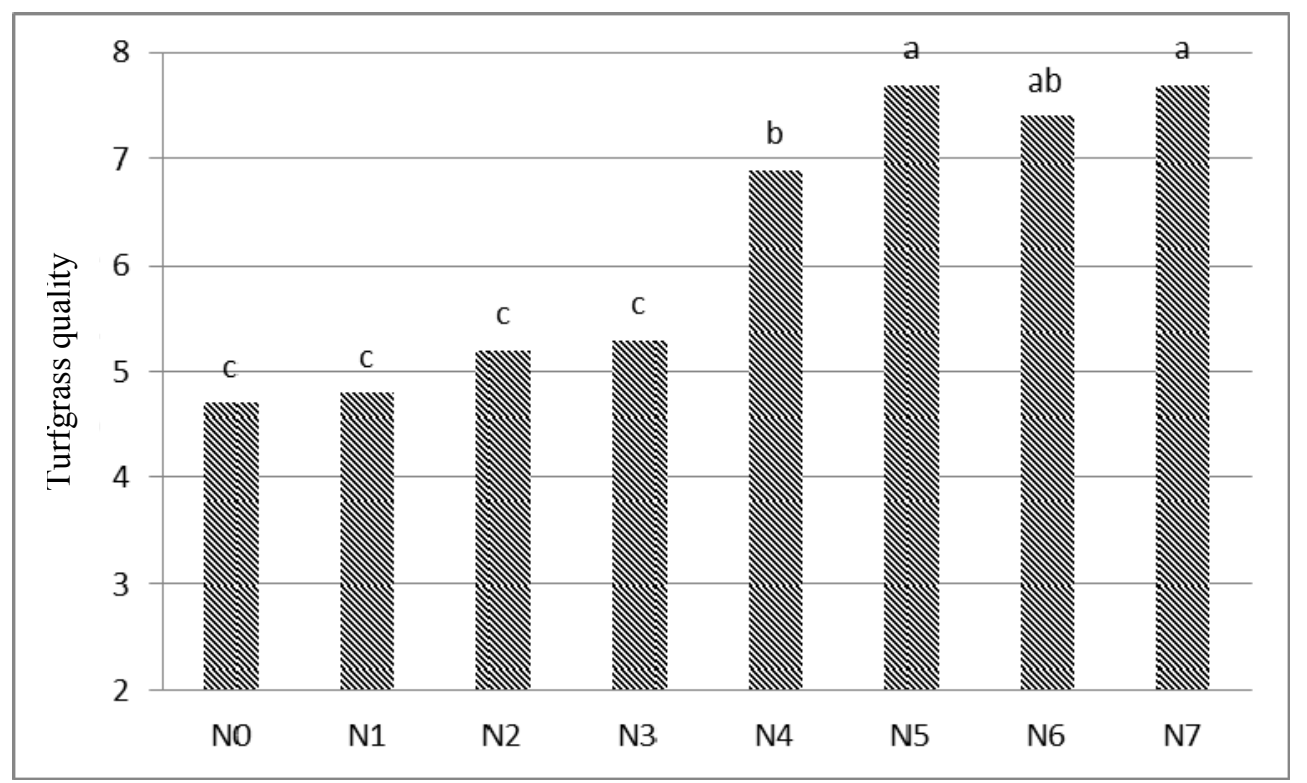

Fig. 11 Effects of $\mathrm{N}$ rates on the quality of Lolium perenne $\mathrm{L}$..

Rated on a 1-9 scale ( $9=$ the optimum turfgrass quality).

In each column, the same letters are not significant different using DMRT at 5\% probability level. 


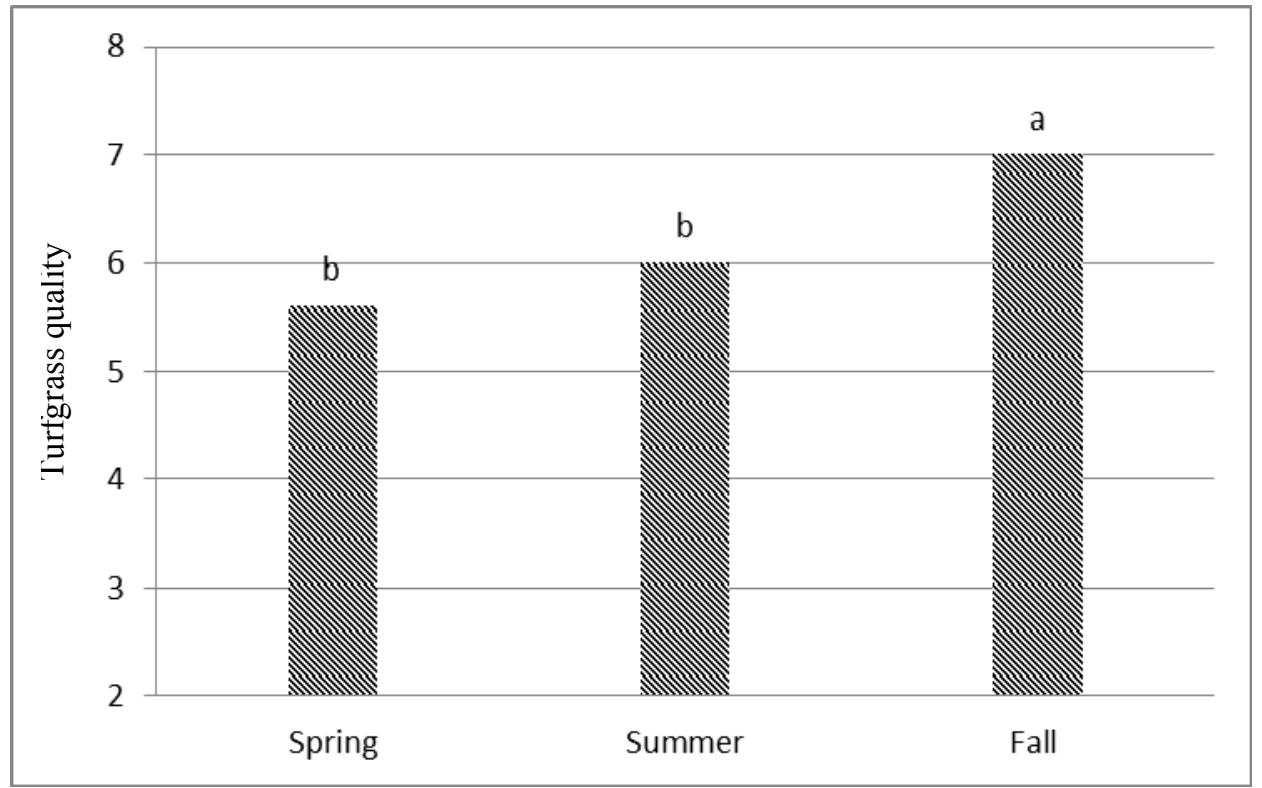

Fig. 12 Effects of seasons on the quality of Lolium perenne L..

Rated on a 1 to 9 scale ( 9 = the optimum turfgrass quality).

In each column, the same letters are not significant different using DMRT at $5 \%$ probability level.

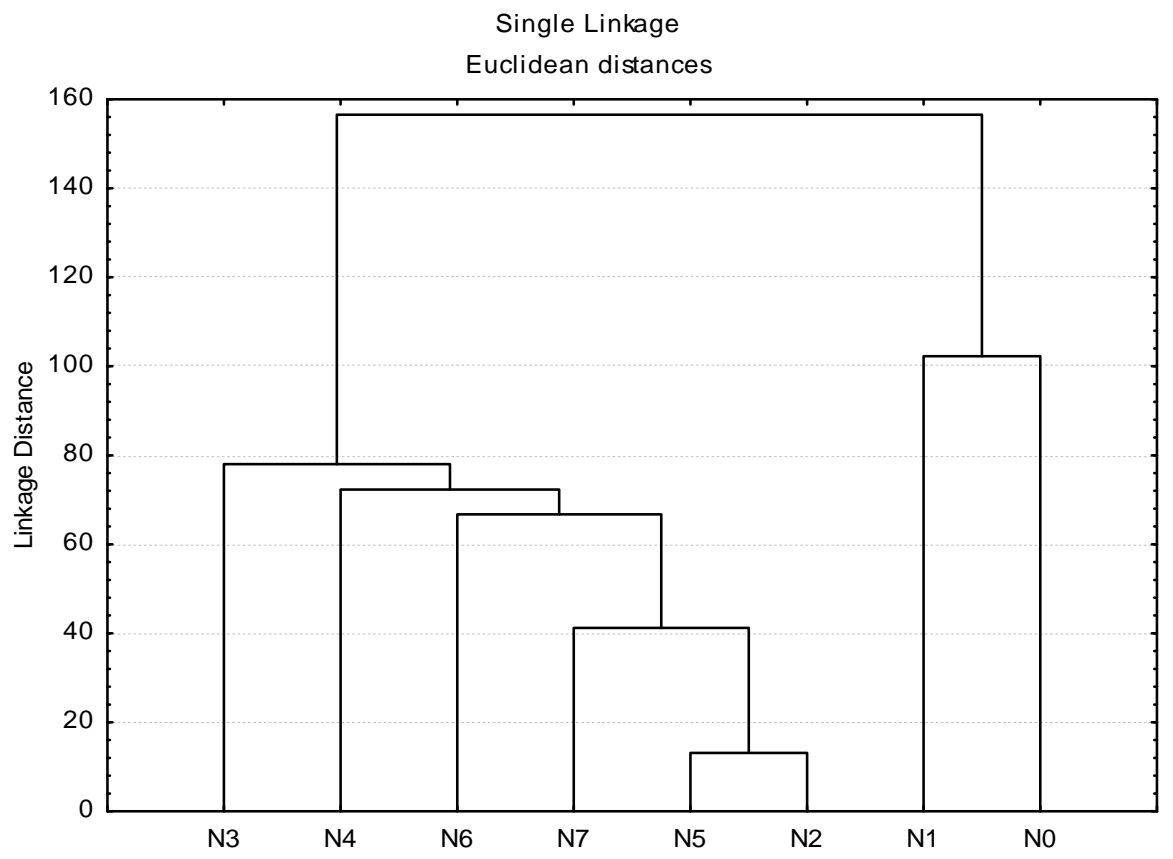

Fig. 13 Cluster analysis of $\mathrm{N}$ application on the Lolium perenne $\mathrm{L}$..

Perennial ryegrass stability in cultivation for seeds depends on natural habitat conditions [6], cultivar physiological properties and the way of utilization as well as agronomic factors [7] shaping plant growth, development and yield. Salman and Avcioğlu [25] indicated that intensive fertilizer treatment was necessary for the loam and sparsely textured soil; 500 $\mathrm{kg} / \mathrm{ha}$ combined fertilizer (N-P-K; 12-12-12) per year was for the best results whether purely sown with Lolium perenne and Festuca arundinacea or mixtures.

The cluster is the technique of grouping rows together that share similar values across some variables. 


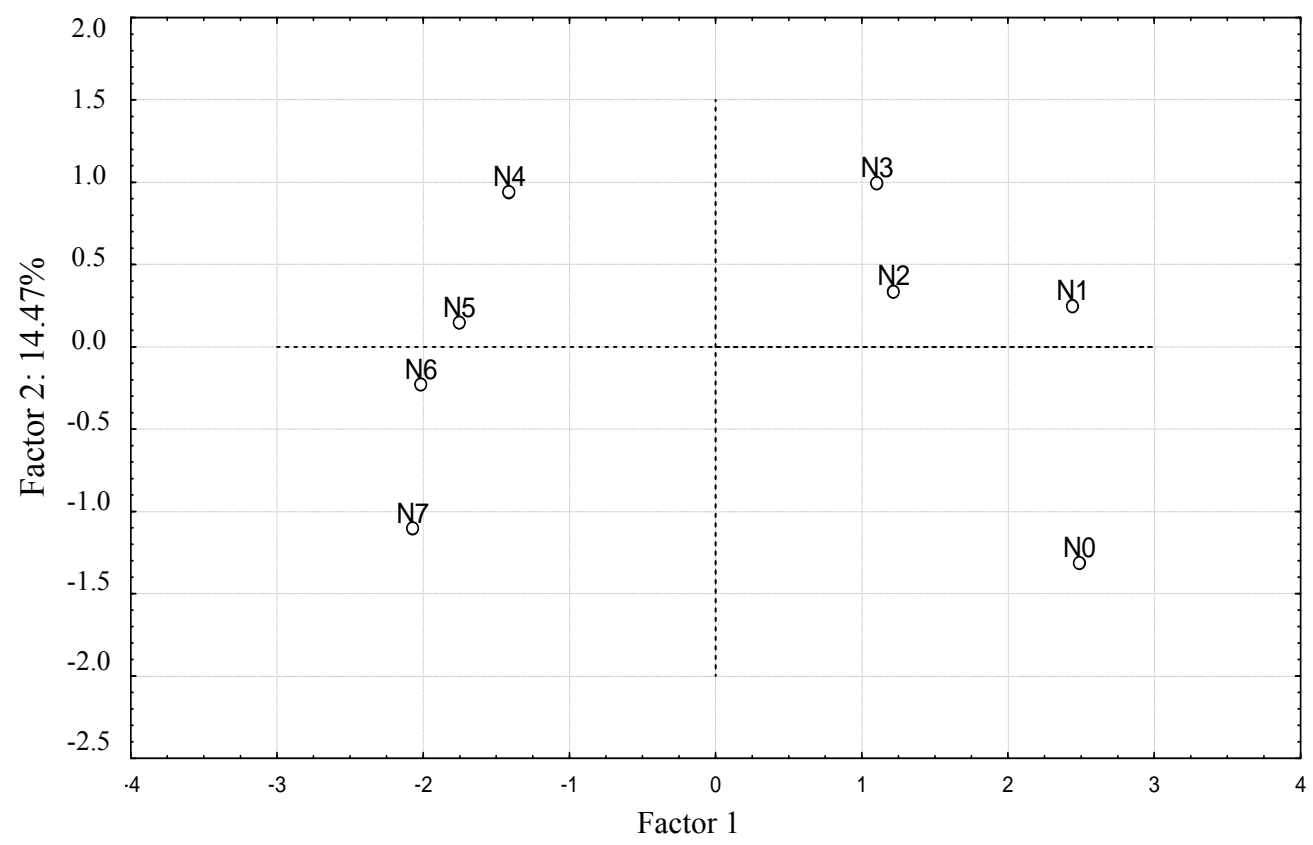

Fig. 14 Principal component analysis of $\mathrm{N}$ application on the Lolium perenne $\mathrm{L}$..

Except for control (N0), applications are clustered together. Unlike other $\mathrm{N}$ dose applications, N2, N5, N7, N6, N4 and N3 were located in the same basic group. N2 and N5 in the same group; N7 and N6, N4 and $\mathrm{N} 3$ are divided into separate branches within this group (Fig. 13). The goal of principal component analysis (PCA) is to preserve as much information contained in the data as possible (Fig. 14). Consequently, it showed that $\mathrm{N}$ fertilizers had a very close effect on all characters investigated in Lolium perenne L. (Figs. 13 and 14). Russi at al. [26] concluded that the turfrass quality is largely dependent on the genotype and environment interaction.

\section{Conclusions}

A newly seeded area should be irrigated to provide moisture to the whole seedbed. Irregular irrigation can be detrimental to couch grass production, especially during establishment. At the beginning of the experiment, there were some difficulties in supplying sufficient irrigation water. Newly seeded turf plants have poorly developed root systems and can not take up nutrients from the soil effectively. Therefore, it is important to fertilize frequently to encourage establishment. $\mathrm{N}$ should be applied sufficiently but not abundantly. Taking everything into account, the $\mathrm{N}$ fertilization at the dose $40.0-50.0 \mathrm{~kg} \mathrm{~N} / \mathrm{ha}$ per month was sufficient during the seven months in the first year for perennial grown for seeds on light soil. In this way, a balanced relationship between soil and crops can evolve to ensure crops are maintained in a healthy state.

\section{References}

[1] Mohammad, P. 2008. Handbook of Turfgrass Management and Physiology. Boca Raton, FL: CRC Press.

[2] Heckman, J. R., Liu, H., Hill, W., De Milia, M., and Anastasia, W. L. 2000. "Kentucky Bluegrass Responses to Mowing Practice and Nitrogen Fertility Management." J. Sustain Agr. 15 (4): 25-33.

[3] Dunn, J., and Diesburg, K. 2004. Turf Management in the Transition Zone. Hoboken, New Jersey: John Wiley \& Sons.

[4] Kryzeviciene, A., and Zemaitis, V. 1999. "Cereal Seed-Grass Species Productivity at Stand Aging." Biologija 1: 12-4.

[5] Martyniak, J., and Domański, P. 1983. "Seed Yield Fluctuations in Cultivars and Species of Forage Grasses." Zesz. Probl. Post. Nauk Rol. 282: 67-79. (in Polish)

[6] Jurek, M. 1987. "Natural Habitat Factors Limiting 
Stability of Lolium perenne L..” Biul. IHAR 162: 113-22. (in Polish)

[7] Szczepanek, M. 2006. "Stability of Perennial Ryegrass (Lolium perenne L.) Plants Cultivated for Seeds at Varied Levels of Nitrogen Fertilization." Electronic Journal of Polish Agricultural Universities 9 (4): 56. Accessed December 21 , 2006. http://www.ejpau.media.pl/volume9/issue4/art-56.html.

[8] Yılmaz, M., Avcığlu, R., Salman, A., and Cevheri, C. 2012. "Problems Encountered in Turf Establishment Activities and Suggestions for Solutions in Turkey." Journal of Turkish Scientific Collections 5 (2): 60-3.

[9] Falkowski, M., Olszewska, L., Kukułka, I., and Kozłowski, S. 1986. "Response of Perennial Ryegrass (Lolium perenne L.) Cultivars to Nitrogen and Water." Biul. Oceny Odmian 11: 103-11. (in Polish)

[10] Nodrestgaard, A. 1992. "Split Nitrogen Application in Perennial Ryegrass (Lolium perenne L.) for Seed Production in Danish." Tidsskr. Planteavl 96: 163-8. (in Danish)

[11] Salehi, H., and Khosh-Khui, M. 2004. "Turfgrass Monoculture, Cool-Cool and Cool-Warm Season Seed Mixture Establishment and Growth Responses." HortScience 39 (7): 1732-5.

[12] SAS Institute, Inc.. 1991. SAS/STAT User's Guide. Cary, NC: SAS.

[13] Barre, P., Gueye, B., and Gastal, F. 2010. "Effect of Light Quality and Quantity on Leaf Growth in Lolium perenne L." In Sustainable Use of Genetic Diversity in Forage and Turf Breeding, edited by Huyghe, C. Berlin, Germany: Springer, 61-5.

[14] Wilkins, P. W. 1991. "Breeding Perennial Ryegrass for Agriculture.” Euphytica 52 (3): 201-4.

[15] Zorer, Ş., Hosaflıoğlu, İ., and Yılmaz, İ. H. 2004. "Determination of Proper Nitrogen Fertilization Application Times in Turfgrass." YYÜ J. Agric. Sci. 14 (1): 27-34.

[16] Starr, J. L., and De Roo, H. C. 1981. "The Fate of Nitrogen Applied to Turfgrass." Crop Sci. 21 (4): 531-6.

[17] Petrovic, A. M., Hummel, N. W., and Carroll, M. J. 1986. "Nitrogen Source Effects on Nitrate Leaching from Late
Fall Nitrogen Applied to Turfgrass." In Proceeding of the First International Conference on Turfgrass Management and Science for Sports Fields, 137.

[18] Wilman, D., and Pearse, P. J. 1989. "Effects of Applied Nitrogen on Grass Yield, Nitrogen Content, Tillers and Leaves in Field Swards." Journal of Agricultural Science 103 (1): 201-11.

[19] Harris, S. L., Thom, E. R., and Clark, D. A. 1996. "Effect of High Rates of Nitrogen Fertilizer on Perennial Ryegrass Growth and Morphology in Grazed Dairy Pasture in Northern New Zealand." New Zealand Journal of Agricultural Research 39 (1): 159-69.

[20] Gautier, H., and Varlet-Grancher, C. 1996. "Regulation of Leaf Growth of Grass by Blue Light." Physiol. Plant. 98 (2): 424-30.

[21] Snyder, G. H., Augustin, B. J., and Davidson, J. M. 1984. "Moisture Sensor-Controlled Irrigation for Reducing N Leaching in Bermudagrass Turf." Agronomy J. 76 (6): 964-9.

[22] Goatley, J. M., Maddox, V., Lang, D. J., and Crouse K. K. 1994. “Tifgreen' Bermudagrass Response to Late-Season Application of Nitrogen and Potassium." Agronomy J. 86 (1): 7-10.

[23] Candogan, B. N., Bilgili, U., Yazgan, S., and Açıkgöz, E. 2015. "Irrigation Level and Nitrogen Rate Affect Evapotranspiration and Quality of Perennial Ryegrass (Lolium perenne L).” Int. J. Agric. Biol. 17 (3): 431-9.

[24] Barton, L., Wan, G. G. Y., and Colmer, T. D. 2006. "Turfgrass (Cynodon dactylon L.) Sod Production on Sandy Soils: Part I, Effects of Irrigation and Fertilizer Regimes on Growth and Quality." Plant and Soil 284 (1): 129-45.

[25] Salman, A., and Avcığlu, R. 2010. "Performances of Some Cool Season Turfgrasses in Different Fertilizer Doses." Ege Üniv. Journal of Faculty of Agriculture 47 (3): 309-19.

[26] Russi, L., Annicchiarico, P., Martiniello, P., Tomasoni, E., Piano, C., and Veronesi, F. 2004. "Turf Quality and Reliability in Varieties of Four Turf Speciess in Contrasting Italian Environments." Grass and Forage Science 59 (3): 233-9. 